February 2003 - NREL/TP-620-33475

\title{
Understanding the Environmental Impacts of Electricity: Product Labeling and Certification
}

\author{
L.A. Bird
}

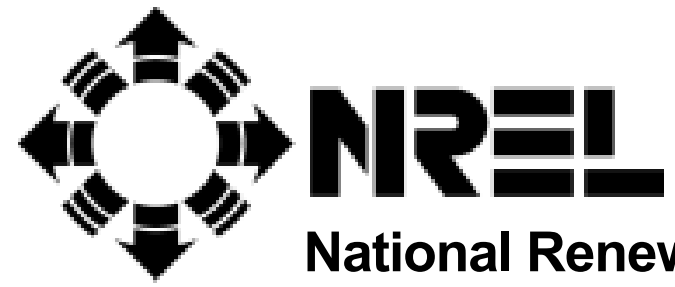

1617 Cole Boulevard

Golden, Colorado 80401-3393

NREL is a U.S. Department of Energy Laboratory

Operated by Midwest Research Institute $\bullet$ Battelle $\bullet$ Bechtel

Contract No. DE-AC36-99-G010337 
February 2003 • NREL/TP-620-33475

\section{Understanding the Environmental Impacts of Electricity: Product Labeling and Certification}

L.A. Bird

Prepared under Task No. AS72.1006

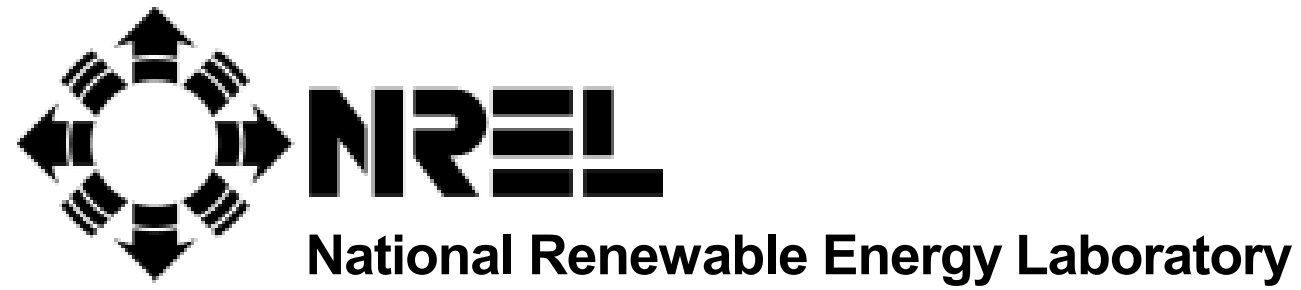

1617 Cole Boulevard Golden, Colorado 80401-3393

NREL is a U.S. Department of Energy Laboratory Operated by Midwest Research Institute • Battelle • Bechtel 


\section{NOTICE}

This report was prepared as an account of work sponsored by an agency of the United States government. Neither the United States government nor any agency thereof, nor any of their employees, makes any warranty, express or implied, or assumes any legal liability or responsibility for the accuracy, completeness, or usefulness of any information, apparatus, product, or process disclosed, or represents that its use would not infringe privately owned rights. Reference herein to any specific commercial product, process, or service by trade name, trademark, manufacturer, or otherwise does not necessarily constitute or imply its endorsement, recommendation, or favoring by the United States government or any agency thereof. The views and opinions of authors expressed herein do not necessarily state or reflect those of the United States government or any agency thereof.

Available electronically at http://www.osti.gov/bridge

Available for a processing fee to U.S. Department of Energy and its contractors, in paper, from:

U.S. Department of Energy

Office of Scientific and Technical Information

P.O. Box 62

Oak Ridge, TN 37831-0062

phone: 865.576 .8401

fax: 865.576.5728

email: reports@adonis.osti.gov

Available for sale to the public, in paper, from:

U.S. Department of Commerce

National Technical Information Service

5285 Port Royal Road

Springfield, VA 22161

phone: 800.553.6847

fax: 703.605.6900

email: orders@ntis.fedworld.gov

online ordering: http://www.ntis.gov/ordering.htm 


\section{TABLE OF CONTENTS}

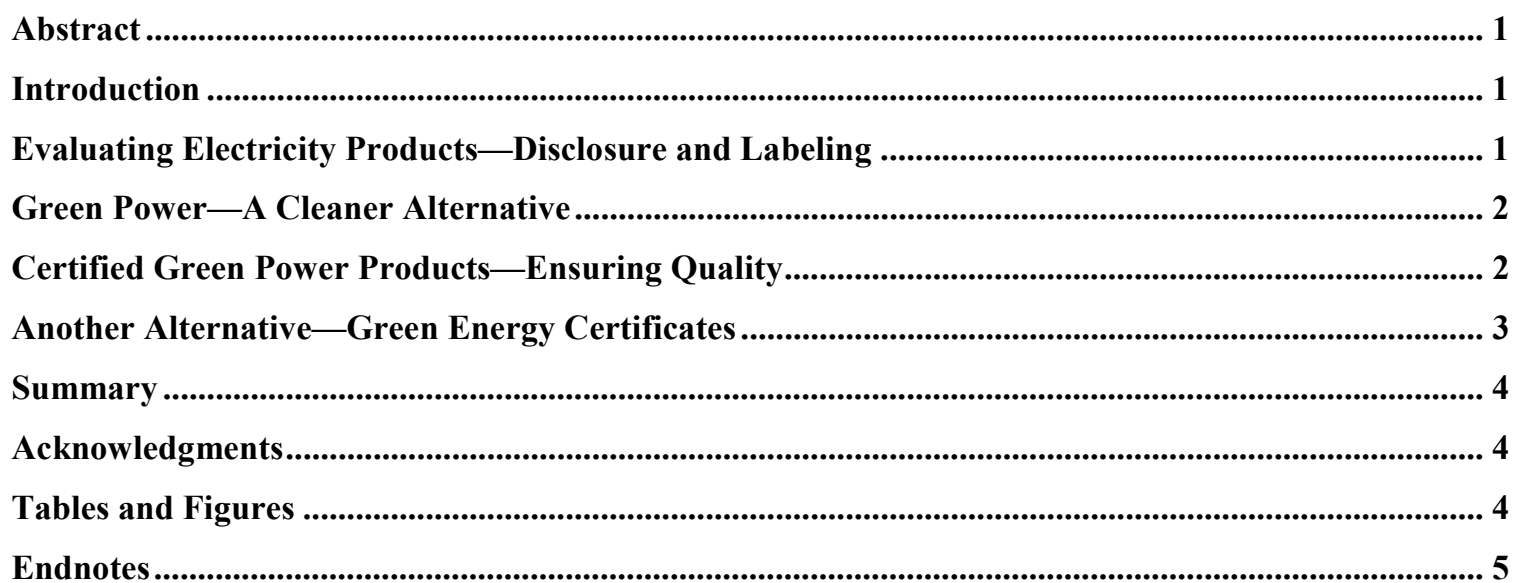




\begin{abstract}
Electricity consumers are increasingly gaining the ability to choose among power options from either their current electric utilities or from alternative power providers. In order to help consumers make informed decisions about their electricity purchases and to compare alternatives, many states are requiring electricity providers to disclose information regarding the fuel sources used to generate electricity and their associated environmental impacts. Like nutrition labels, environmental disclosure labels present the content or sources of electricity and are typically included with electricity bills and in product offers. These labels allow consumers to compare the environmental impacts of standard and cleaner power options, which are typically available. In fact, more than one-third of electricity customers have access to green powerpower generated from renewable sources such as solar, wind, hydro, geothermal, and biomass - directly through a power supplier. And green energy certificates, which represent the environmental attributes of renewable resources, are available nationally - even where the actual resource does not exist. Some products are certified by environmental organizations that verify the sources of power and ensure that environmental benefits are accrued. This paper discusses clean, green power options available to power purchasers and the tools and information that can be used to make more sustainable power purchase decisions.
\end{abstract}

\title{
Introduction
}

Nationally, most of our electricity is generated from coal (52\%), nuclear (20\%), and natural gas (16\%), with the remainder supplied from hydro (7\%), oil (3\%), and other renewable sources (2\%) [1]. The environmental implications of our nation's fuel mix are considerable. According to the U.S. Environmental Protection Agency (EPA), the fuel sources currently used to produce electricity are responsible for emitting about two-thirds of the sulfur dioxide, one-third of the mercury, and one-quarter of the nitrogen oxides emitted in the United States [2]. In addition, fossil-based energy sources contribute significantly to emissions of fine particulate matter and carbon dioxide, a leading greenhouse gas. (The sources used to generate electricity vary considerably by region; thus, specific data is necessary to determine the environmental impacts of power purchases in a particular location.)

Many consumers now have the power to reduce their environmental footprint by reducing their use of fossil-based fuels. With the movement toward competition in the electric utility industry, they can choose their suppliers and purchase power generated from cleaner resources. But with more options to choose from, consumers must fully understand the environmental implications of their power purchase options.

\section{Evaluating Electricity Products—Disclosure and Labeling}

In an effort to enable consumers to make informed decisions when choosing electricity suppliers, many states have adopted policies requiring retail power providers to clearly divulge information about the sources of their electricity and the environmental characteristics of these sources. Using this information, consumers can assess the environmental implications of their electricity consumption and determine whether cleaner alternatives are available.

There are now about 20 states that require power suppliers to disclose environmental information on marketing materials and in product offers. Some states, such as California, require disclosure of only the fuel mix (see Figure 1); while other states, such as Texas, also require data on environmental impacts, such as air pollutant emissions and nuclear waste (see Figure 2). Most, but not all, states require electricity providers to use a standard format, allowing consumers to easily compare a variety of product offers. A few require suppliers to make this information easily accessible on a single Internet site. Table 1 lists states with environmental disclosure policies, including how and when this data must be presented [3].

There are a few things to consider when using this data. First, is the information provided for a specific product or the company's entire resource mix? Are the fuel mix and emissions compared to the regional or state average? Is information supplied for all of the major environmental impacts? Is data available for both default suppliers and new market entrants to allow comparison? Does the supplier disclose its actual 
mix or the system mix? Some states allow suppliers to present the average system mix if they are not making specific claims about their resource mix. Finally, if the product is supplied from renewable sources, are the specific types of resources specified? If all of these questions are not answered, the information may not be presenting a clear picture of the environmental impacts to enable you to compare products on an equal basis.

\section{Green Power-A Cleaner Alternative}

If your standard power mix is heavily dependent on fossil fuels and nuclear, you may be interested in pursuing a cleaner alternative. Depending on your location, you may be able to select a "green power" product or choose one with environmentally preferred characteristics. "Green power" generally refers to electricity supplied in whole or in part from renewable energy sources, such as wind and solar power, geothermal, hydropower, and biomass. By choosing to purchase green power, you can support the development of renewable energy sources, which can reduce the burning of fossil fuels, such as coal, oil, and natural gas. Greater reliance on renewable sources also provides economic benefits and can improve our national energy security.

More than one-third of retail customers in the United States have the option to purchase green power directly from an electricity supplier. Green power is now available in states with retail electricity competition, including Connecticut, Maryland, New Jersey, Pennsylvania, Texas, Virginia, and other New England states. It is also likely to be available soon in New York. Even in states without electricity market competition, green power may be offered by incumbent, regulated utilities. Currently, more than 90 utilities in 30 states offer green power options to their customers. In most cases, these programs are open to commercial and industrial customers as well as residential customers [4].

\section{Certified Green Power Products—Ensuring Quality}

Some green power products are certified by independent organizations. Certification programs can help ensure that 1) the power you are purchasing is actually delivered to the grid from the specified sources, and 2) the product will result in substantial environmental benefits. Most certification groups serve as thirdparty auditors who verify that green power marketers provide power from the appropriate sources in the appropriate quantities to their customers. They typically also set stringent standards for product content.

Green-e is the leading national certification and verification program for environmentally preferred electricity products offered in competitive power markets. It is administered by the Center for Resource Solutions, a non-profit environmental organization based in San Francisco. To be eligible for Green-e certification, at least half of an electricity product's energy supply must come from renewable resources such as wind, solar, geothermal, biomass, or small hydro. The product must also contain a percentage of recently developed (new) renewable resources. Any non-renewable portion of the product must be as clean or cleaner and must not contain more nuclear energy than the traditional power mix. In addition, certified suppliers must disclose their power sources to customers and agree to an annual third-party audit to verify their marketing claims. The Green-e program has a number of regional advisory committees that set specific regional standards with respect to issues such as eligible renewable resources and new renewable energy content. Regional advisory committees have been created in California, the Midatlantic, New England, New York, Ohio, and Texas. Nationally, Green-e certifies more than 20 retail and wholesale green power products in California, Connecticut, New Jersey, and Pennsylvania. Commercial and industrial customers purchasing Green-e certified products are able to use the Green-e logo in advertising in accordance with the program's secondary-use standards [5].

The Center for Resource Solutions also administers a national Green Pricing Accreditation Program for green power programs offered by utilities in non-competitive markets. The program is designed to recognize utility programs that use "best practices" in offering green electricity options to customers. Utility green pricing programs can become accredited if they meet or exceed stringent standards regarding renewable resource content, product pricing, marketing activities, and information disclosure. Accredited utilities are also required to undergo an annual, independent verification process to document their green power deliveries. To date, green pricing accreditation standards are in place in Colorado, Wisconsin, Iowa 
and the service territory of the Tennessee Valley Authority (TVA), while standards are under development in Florida, Georgia, Minnesota, North Carolina, North Dakota and South Carolina. Accredited utilities and commercial and industrial customers purchasing green power through accredited utility programs are able to use the Green-e logo [6].

Renew 2000 is a certification program available for green power products offered in the Pacific Northwest. Green power products are eligible for certification under the program if they meet certain criteria regarding resource content, including newly developed renewables, program design, fuel mix disclosure, and marketing. The product standards were developed by a regional coalition of environmental groups, utilities, and governments [7].

Although not a certification program per se, another tool available for evaluating the environmental impact of electricity products is the Power Scorecard, a Web-based information tool created by a coalition of environmental groups that lets consumers compare the environmental impacts of green power and conventional power products. The Power Scorecard rates electricity products on a scale from "excellent" to "unacceptable" using two measures: 1) the environmental impact on air, land and water, and 2) the amount of energy generated from recently developed renewable, low-impact sources. It was developed jointly by Environmental Defense, the Izaak Walton League of America, the Natural Resources Defense Council, the Northwest Energy Coalition, and the Union of Concerned Scientists, with technical support from the Pace Law School Energy Project [8].

\section{Another Alternative-Green Energy Certificates}

Whether or not green power is available through your local utility or a competitive electricity marketer, another option is to purchase green energy certificates. Also known as green tags, renewable energy certificates, or tradable renewable certificates - green energy certificates represent the environmental attributes of power generated from renewable electric plants. A number of organizations offer green energy certificates separate from electricity service (i.e., customers do not need to switch electricity suppliers in order to purchase these certificates) [9].

For example, PG\&E Corporation offers businesses and others the opportunity to purchase wind energy certificates representing the air emissions avoided with each megawatt-hour of power supplied from its 11.5-MW wind project in Madison County, New York. One of the company's larger customers is Kinko's, which purchases wind certificates for up to $50 \%$ of the energy used by its retail operations in New York.

Another example is the Oregon-based non-profit Bonneville Environmental Foundation (BEF), which markets green energy certificates generated from renewable resources in the Pacific Northwest in cooperation with the Bonneville Power Administration. The Foundation uses revenues from the sales of certificates to expand a fund earmarked for renewable resource development in the Pacific Northwest. BEF supplies green certificates to a number of companies including Xantrex Technology, a leading supplier of inverters for renewable energy systems, Batdorf \& Bronson Coffee Roasters of Olympia, and Global Energy Concepts, a Kirkland-based renewable-energy consulting firm.

Purchasing green energy certificates can be advantageous for a number of reasons. First, there is no need to change electricity suppliers. Second, a single purchase can be used to supply green power to facilities in different locations, which can reduce transaction costs for companies with multiple facilities. In addition, it may be possible to lower costs by supporting renewable projects developed in areas with the best resources, rather than purchasing from local projects that are less efficient. Finally, green certificates are readily available today, whereas renewable energy facilities may not be available in many areas to supply green power locally.

Despite the significant advantages of purchasing green energy certificates, there are some concerns. First, green certificate suppliers are not necessarily energy suppliers and may not fall under the jurisdiction of a utility regulatory commission. Further, they are not necessarily licensed suppliers and, without a license to revoke, it may be more difficult to take disciplinary action against them. Double counting is also a real concern. It is important to ensure that green energy certificates represent the energy generated from a 
particular facility at a particular time and that they are not sold twice. Contracts should specify that the energy must be sold only once. It may also be prudent to contract with a third-party auditor to verify the source of the certificates.

Some environmental organizations are beginning to play a role in certifying and verifying green certificate products. For example, Environmental Resources Trust, a non-profit, environmental organization, certified the first wholesale green certificate product offered in Illinois by ComEd. The group also announced plans to team with Sterling Planet, a retail green energy certificate supplier, to verify a portion of the company's supply.

In addition, the Green-e program is in the process of developing standards for certifying certificate-based green power products. The standards, which are being developed with the assistance of a national advisory committee, address issues such as disclosure, double counting, and new renewables content. Green-e expects to issue final certification standards for certificate-based products in early 2002.

\section{Summary}

With a greater degree of choice now available in electricity markets, consumers have the opportunity to improve their environmental footprint and purchase electricity from cleaner, renewable sources. There are a number of tools available to help evaluate these products. First, many states are requiring electricity suppliers to disclose information about their resource mix and the environmental impacts associated with it. This information can serve as a starting point for evaluating alternatives. In addition, certification programs, such as Green-e, are available to help evaluate green power products offered in the marketplace. Another option, and one that may be particularly appealing to large corporations, is green energy certificates. Overall, no matter what the status of electricity restructuring in your state, cleaner power products exist and there are a variety of tools available to help understand and evaluate the environmental implications of available options.

\section{Acknowledgments}

This research was funded by the U.S. Department of Energy's Office of Energy Efficiency and Renewable Energy through the Office of Power Technologies. Additional information on state environmental disclosure policies and green power certification programs is available through the Green Power Network Web site at http://www.eren.doe.gov/greenpower/. The author thanks the U.S. Department of Energy for their support of this work.

\section{Tables and Figures}

Table 1: Environmental Disclosure Requirements for Electricity Suppliers by State

Figure 1: California Power Content Label

Figure 2: Texas Electricity Facts Label

Figure 3: Green-e Logo 


\section{Endnotes}

[1] Energy Information Administration, Electric Power Annual 2000: Volume 1. Table 6.Net Generation by Energy Source and Sector, 2000 and 1999. August 2001.

http://www.eia.doe.gov/cneaf/electricity/epav1/generation.html

[2] U.S. EPA, National Air Pollutant Emission Trends, 1900-1998 (EPA-454/R-00-002), March 2000, Figures 2-2, 2-4, www.epa.gov/ttn/chief/trends/trends98/trends98.pdf; and U.S. EPA, 1996 National Toxics Inventory, September 2000, www.epa.gov/ttn/chief/nti.

[3] L. Bird and D. Lackaff. Summary of State Environmental Disclosure Policies, National Renewable Energy Laboratory, October 2001 http://www.eren.doe.gov/greenpower/disclosetxt.shtml

[4] B. Swezey and L. Bird, Green Power Marketing in the United States: A Status Report, NREL/TP-62028738. Golden: CO: National Renewable Energy Laboratory, August 2000.

[5] For more information on the Green-e certification program, see http://www.green-e.org.

[6] For more information on the Green Pricing Accreditation Program, see http://www.resourcesolutions.org/CRSprograms/greenpricing.html.

[7] For more information on the Renew 2000, see http://www.cleanenergyguide.org.

[8] For more information on the Power Scorecard, see http://www.powerscorecard.org.

[9] For more information on green certificates see Starrs, T. "Green Tags: A New Way to Support Renewable Energy," Solar Today, July/August 2001. 
Table 1. Environmental Disclosure Requirements for Electricity Suppliers by State - October 2001

\section{State \\ Disclosure Requirement}

Full Disclosure Requirements

Standards to be set for disclosure of environmental impacts

California

Fuel mix required in standard format.

Colorado

Fuel mix. Standard format is suggested.

Connecticut

Fuel mix and air emissions

Delaware

Fuel mix

Florida

Illinois

Maine

Maryland

Massachusetts

Fuel mix

Fuel mix and $\mathrm{CO}_{2} ; \mathrm{NOx} ; \mathrm{SO}_{2}$; high- and lowlevel nuclear waste in standard format.

Fuel mix and $\mathrm{CO}_{2} \mathrm{NO}_{x} ; \mathrm{SO}_{2}$ emissions in format similar to sample

Michigan

Fuel mix and $\mathrm{CO}_{2} ; \mathrm{NO}_{x} ; \mathrm{SO}_{2}$ emissions in standard format

Fuel mix and $\mathrm{CO}_{2} ; \mathrm{NO}_{\mathrm{x}} ; \mathrm{SO}_{2}$ emissions in standard format

Minnesota

Fuel mix and $\mathrm{SO}_{2} ; \mathrm{CO}_{2} ; \mathrm{NO}_{x}$; high-level nuclear waste emissions in standard format

Minnesota

New Jersey Fuel mix, energy efficiency, and $\mathrm{CO}_{2} ; \mathrm{SO}_{2} ; \mathrm{NO}$

Fuel mix, air pollutant emissions, and nuclear waste emissions in standard brochure $\mathrm{x}$ emissions in standard format

New Mexico Fuel mix and associated emissions, standard format required under proposed rules

New York

Fuel mix and $\mathrm{CO}_{2} ; \mathrm{SO}_{2} ; \mathrm{NO}_{\mathrm{x}}$ emissions in standard format

Ohio Fuel mix, $\mathrm{CO}_{2} ; \mathrm{SO}_{2} ; \mathrm{NO}_{\mathrm{x}}$ emissions and highand low-level radioactive waste in standard format

Oregon

Fuel mix and $\mathrm{CO}_{2} ; \mathrm{SO}_{2} ; \mathrm{NO}_{\mathrm{x}}$; spent nuclear fuel emissions in standard format

Texas

Fuel mix and $\mathrm{CO}_{2} ; \mathrm{SO}_{2} ; \mathrm{NO}_{x}$; Particulates; nuclear waste emissions in standard format

Washington

Fuel mix in standard format

\section{Partial Disclosure Requirements ${ }^{1}$}

Arizona

Fuel mix and emissions to extent reasonably known

District of

Fuel mix

Columbia

Pennsylvania

Fuel mix and energy efficiency

Virginia

Fuel mix and emissions to the extent feasible

Proposed Disclosure Requirements

Montana

Fuel mix and $\mathrm{CO}_{2} ; \mathrm{SO}_{2} ; \mathrm{NO}_{\mathrm{x}}$, spent nuclear waste, hydro

West Virginia

Fuel mix and $\mathrm{CO}_{2} ; \mathrm{SO}_{2} ; \mathrm{NO}_{\mathrm{x}}$ and high-level and low-level nuclear waste

\section{Frequency}

Method of Distribution

Effective

Date

TBD

Quarterly

Twice annually

TBD

Quarterly

Quarterly

Quarterly

Quarterly

Twice annually

Quarterly

Twice annually

Twice annually

Twice annually

(1)

TBD, proposed annually

Twice annually

Annually plus

quarterly

comparisons

Quarterly

Twice annually

Twice annually

(plus two

referrals)

Upon request

and in

marketing

Twice annually

to Commission

Upon request

Annually to

extent feasible

Twice annually

Supplied to

Commission quarterly
TBD

TBD

Bill insert, offers, and written promotional materials

Bill insert or mailing

1999

TBD

1999

TBD

Bill insert or mailing, offers, marketing materials

On bill or bill insert

Bill insert

1999

1999

1998

Bill insert or mailing and prior to initiation of service.

1999

Bill insert or mailing and with contracts

Bill insert and prior to initiation of service.

2000

1998

Bills and on Commission web site

Web, phone referral on bill, full info on bill insert

Mailings, direct mail marketing, solicitations, contracts

TBD

Bill insert and prior to offers

Bill insert or mailing, and contracts

On bill or insert, marketing,

contracts, URL on bill

Bill insert or mailing, solicitations, web site

Bill insert or mailing, solicitations

Upon request

Supplied only to the

Commission

Supply to Commission annually

"Reported to customers."

Product offers, contracts, ads

TBD

Solicitations

TBD

Posted on company web site

${ }^{1}$ The term partial disclosure requirements refers to policies that are not mandatory, do not apply to all retail electricity suppliers, or do not result in direct disclosure to consumers. 
Figure 1: California Fuel Source Disclosure Label

\begin{tabular}{|c|c|c|}
\hline \multicolumn{3}{|c|}{ POWER CONTENT LABEL } \\
\hline $\begin{array}{l}\text { ENERGN } \\
\text { RESOURCES }\end{array}$ & 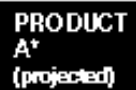 & 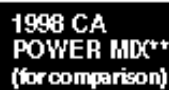 \\
\hline Eligible Renewable & $55 \%$ & 118 \\
\hline -Eiomss: \& waste & - & $2 \%$ \\
\hline Geothermal & - & $5 \%$ \\
\hline Snall hydroeledric & - & $2 \%$ \\
\hline Solar & - & $<1 \%$ \\
\hline - Mind & - & $1 \%$ \\
\hline Coal & $10 x$ & 200 \\
\hline Lange Hydroelectric & $11 \%$ & 228 \\
\hline Natural Gas & $16 \%$ & 318 \\
\hline Huclear & $8 \%$ & 168 \\
\hline Other & $\{1 \%$ & $=18$ \\
\hline TOTAL & $100 \%$ & 1008 \\
\hline \multicolumn{3}{|c|}{ 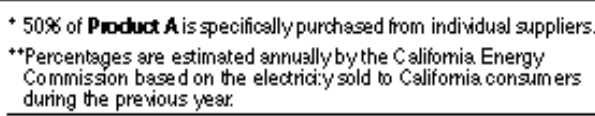 } \\
\hline 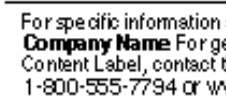 & aliforria Erer & $\begin{array}{l}\text { duct, contact } \\
\text { the Power } \\
\text { momisoion at } \\
\text { sumer }\end{array}$ \\
\hline
\end{tabular}


Figure 2: Texas Electricity Facts Label

(http://www.powertochoose.org/residential/downloads/factslabel.pdf)

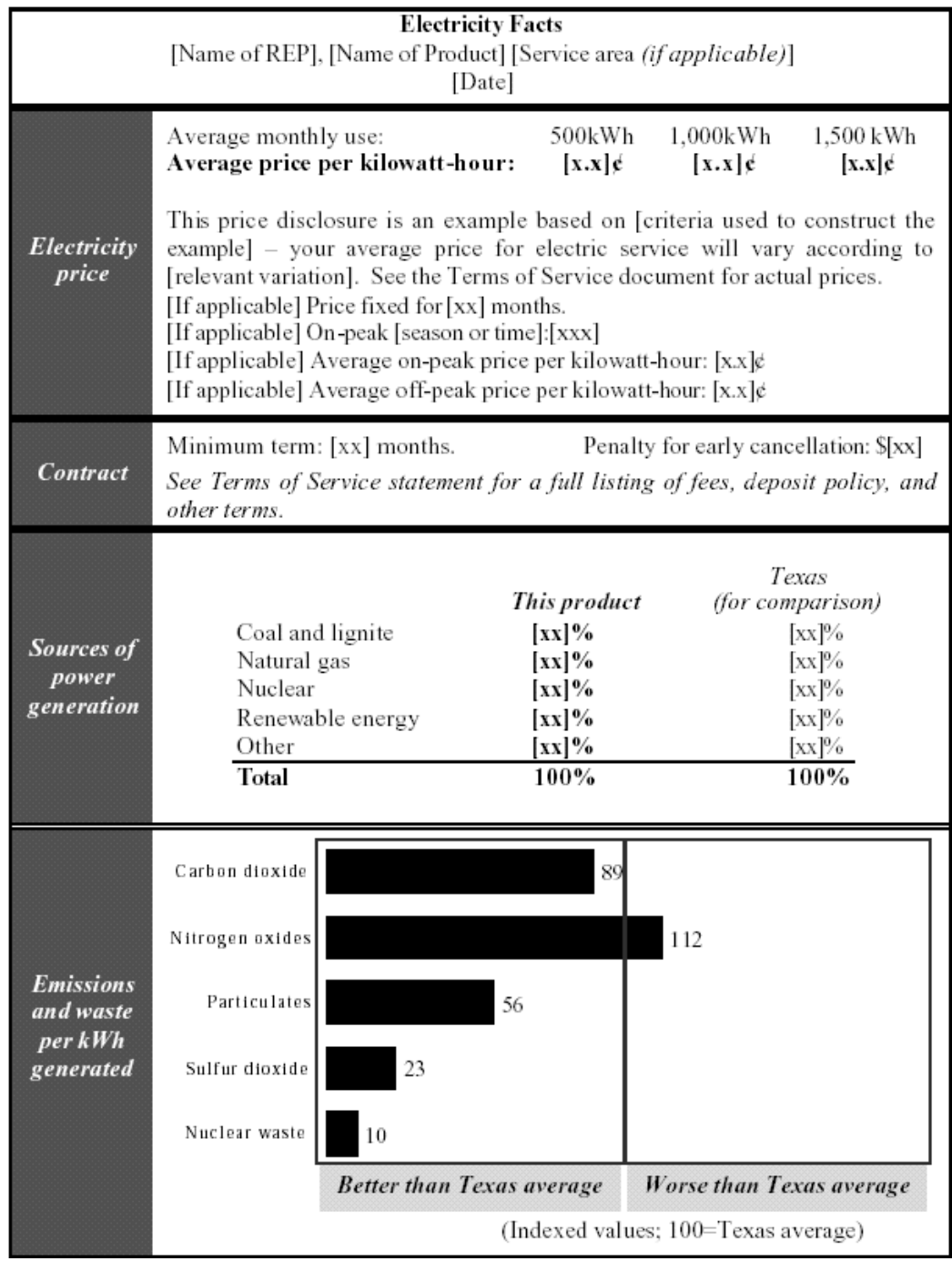


Figure 3: Green-e Certification Program Logo

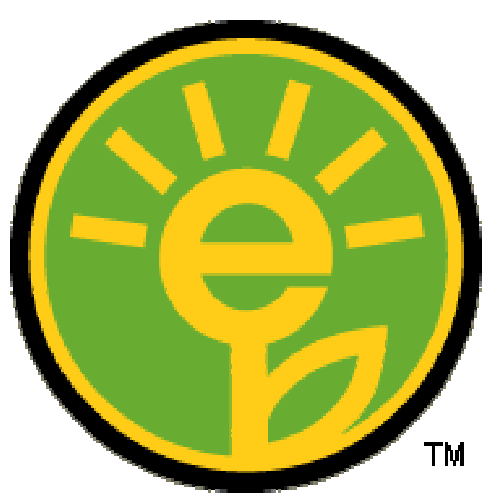




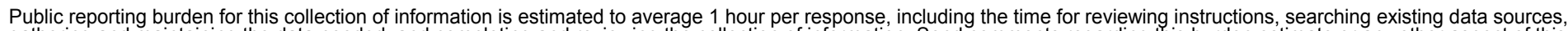

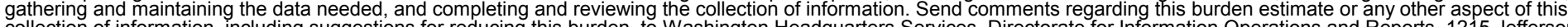
Davis Highway, Suite 1204, Arlington, VA 22202-4302, and to the Office of Management and Budget, Paperwork Reduction Project (0704-0188), Washington, DC 20503.

\begin{tabular}{|l|l|l|}
\hline 1. AGENCY USE ONLY (Leave blank) & $\begin{array}{l}\text { 2. REPORT DATE } \\
\text { February 2003 }\end{array}$ & $\begin{array}{l}\text { 3. REPORT TYPE AND DATES COVERED } \\
\text { Technical Report - Analysis }\end{array}$ \\
\hline
\end{tabular}

\section{TITLE AND SUBTITLE Understanding the Environmental Impacts of Electricity: Product Labeling and Certification}

6. $\operatorname{AUTHOR}(\mathrm{S})$
5. FUNDING NUMBERS

AS72.1006
7. PERFORMING ORGANIZATION NAME(S) AND ADDRESS(ES)

National Renewable Energy Laboratory

1617 Cole Blvd.

Golden, CO 80401-3393
8. PERFORMING ORGANIZATION REPORT NUMBER

NREL/TP-620-33475

9. SPONSORING/MONITORING AGENCY NAME(S) AND ADDRESS(ES)

10. SPONSORING/MONITORING AGENCY REPORT NUMBER

11. SUPPLEMENTARY NOTES

12a. DISTRIBUTION/AVAILABILITY STATEMENT National Technical Information Service 12b. DISTRIBUTION CODE

U.S. Department of Commerce

5285 Port Royal Road

Springfield, VA 22161

ABSTRACT (Maximum 200 word).

Electricity consumers are increasingly gaining the ability to choose among power options from either their current electric utilities or from alternative power providers. In order to help consumers make informed decisions about their electricity purchases and to compare alternatives, many states are requiring electricity providers to disclose information regarding the fuel sources used to generate electricity and the associated environmental impacts. Like nutrition labels, environmental disclosure labels present the content or sources of electricity and are typically included with electricity bills and in product offers. These labels allow consumers to compare the environmental impacts of standard and cleaner power options, which are typically available. This paper discusses clean, green power options available to power purchasers and the tools and information that can be used to make more sustainable power purchase decisions.

14. SUBJECT TERMS
product labeling; certification; Lori Bird; environmental impact; electricity consumers; green power; green energy certificates

17. SECURITY CLASSIFICATION OF REPORT Unclassified
18. SECURITY CLASSIFICATION OF THIS PAGE Unclassified
19. SECURITY CLASSIFICATION OF ABSTRACT Unclassified

15. NUMBER OF PAGES

16. PRICE CODE

20. LIMITATION OF ABSTRACT

UL 